\title{
Identyfikacja genetycznych podstaw procesu kiełkowania w nasionach rzepaku (Brassica napus L.) z wykorzystaniem mapowania genetycznego
}

\author{
Identification of the genetic basis of germination in rape seed (Brassica napus L.) \\ using genetic mapping
}
Katarzyna Gacek ${ }^{1 凶}$, Iwona Bartkowiak-Broda ${ }^{1}$, Laurencja Szala1, Teresa Cegielska-Taras ${ }^{1}$, Philipp E. Bayer², David Edwards², Jacqueline Batley², Steven Penfield ${ }^{3}$

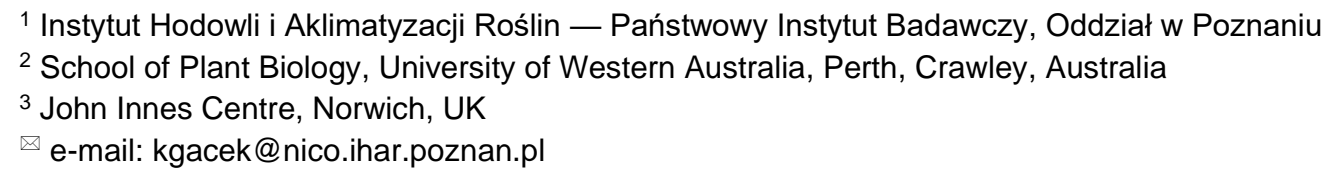

\begin{abstract}
Badano populację mapującą rzepaku ozimego złożoną z 78 linii podwojonych haploidów uzyskanych z mieszańców pochodzących ze skrzyżowania linii różniących się siłą kiełkowania. Siła kiełkowania nasion była automatycznie rejestrowana co 30 min przy pomocy aparatu fotograficznego umieszczonego w minikomputerze Raspberry Pi. Zdjęcia przeanalizowano przy pomocy oprogramowania stworzonego w John Innes Centre. W kolejnym etapie wykorzystując metodę sekwencjonowania całego genomu (Illumina ${ }^{\circledR}$ HiSeq) wszystkich linii populacji mapującej zidentyfikowano polimorfizmy pojedynczego nukleotydu (SNPs) w tych liniach. Dane te posłużą do mapowania genetycznego i identyfikacji genów regulujących proces kiełkowania.
\end{abstract}

\begin{abstract}
Słowa kluczowe: rzepak mapowanie genetyczne, kiełkowanie
The mapping population of winter oilseed rape composed of 78 doubled haploid lines obtained from hybrids originating from the intersection of lines differing in germination power was examined. Seed germination power was automatically recorded every 30 minutes using a camera placed in the Raspberry Pi mini computer. The photos were analyzed using software created at the John Innes Center. In the next step, using the whole genome sequencing method (Illumina ${ }^{\circledR}$ HiSeq) of all mapping population lines, single nucleotide polymorphisms (SNPs) were identified in these lines. This data will be used for genetic mapping and identification of genes regulating the germination process.
\end{abstract}

Key words: rape seed, genetic mapping, germination

Nasiona roślin uprawnych pełnią kluczową rolę $\mathrm{w}$ plonowaniu, a więc zapewnieniu bezpieczeństwa żywnościowego człowieka. O jakości i wielkości plonu $\mathrm{w}$ dużej mierze decyduje wigor nasion, który warunkuje szybkie kiełkowanie oraz wyrównany rozwój siewek w odpowiednich warunkach środowiskowych. Ulepszenie wigoru nasion rzepaku ma istotne znaczenie $\mathrm{w}$ hodowli plennych odmian tego gatunku i aby go uzyskać, należy poznać genetyczne podstawy m.in. kiełkowania. $\mathrm{W}$ tym celu przebadano populację mapującą rzepaku ozimego złożoną $\mathrm{z} 78$ linii podwojonych haploidów (DH) uzyskanych $\mathrm{z}$ mieszańców pochodzących ze skrzyżowania linii różniących się siłą kiełkowania: czarnonasiennej (M305) oraz żółtonasiennej (Z114). Analizę kiełkowania populacji mapującej Z114xM305 przeprowadzono wykorzystując wysokoprzepustową, zautomatyzowaną metodę analizy zdolności i energii kiełkowania, a nasiona badanych linii uzyskano w doświadczeniu przeprowadzonym $\mathrm{w}$ sezonie 2015/2016 w IHAR - PIB Poznań. Doświadczenie prowadzone było $\mathrm{w}$ trzech powtórzeniach w układzie bloków losowych w komorach kiełkowania umieszczonych na półkach w fitotronie $\mathrm{w} 10^{\circ} \mathrm{C}$ i stałym oświetleniu 58W Philips 840 (John Innes Centre, Norwich, UK). Analiza prowadzona była jednocześnie w 12 komorach, a w każdej komorze analizowano 5 linii DH wraz z linią kontrolną. W komorze kiełkowania znajdował się panel wyścielony bibułą nasiąkniętą wodą destylowaną, na której wyłożono po 50 nasion dla każdej analizowanej linii DH. Siła kiełkowania nasion była automatycznie rejestrowana co $30 \mathrm{~min}$ przy pomocy aparatu fotograficznego umieszczonego w minikomputerze Raspberry Pi przymocowanego w górnej pokrywie komory. Każde powtórzenie analizowane było przez $14 \mathrm{dni}$, a podczas każdego 14-dniowego cyklu w 12 komorach analizowano 60 linii DH i 12 kontroli. 
Podczas każdego 14-dniowego cyklu w jednej komorze wygenerowano 672 zdjęcia kiełkujących nasion. Zdjęcia przeanalizowano przy pomocy oprogramowania stworzonego przez zespół bioinformatyków w John Innes Centre, określając długość czasu, w którym wykiełkowało 10, 50 i 90\% nasion (T10, T50, T90, Gmax). Analiza ta wykazała, że badane linie DH posiadają zróżnicowaną zdolność kiełkowania względem linii rodzicielskich, co wraz $\mathrm{z}$ zaobserwowanym zróżnicowaniem w zabarwieniu nasion tych linii wskazuje na transgresję alleli w tej populacji.
W kolejnym etapie badań wykorzystano metodę sekwencjonowania całego genomu (Illumina ${ }^{\circledR}$ HiSeq) wszystkich linii populacji mapującej, oraz zidentyfikowano 187794 polimorfizmów pojedynczego nukleotydu (SNPs) w tych liniach. Pozwoli to wraz z uzyskanymi wynikami testu kiełkowania przeprowadzić mapowanie genetyczne, które umożliwi identyfikację genów regulujących kiełkowaniem nasion. To z kolei umożliwi opracowanie markerów selekcyjnych, które mogą być wykorzystane $\mathrm{w}$ programach hodowlanych plennych odmian rzepaku ozimego.

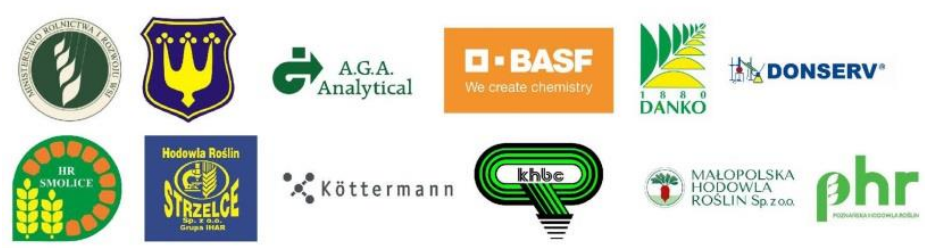

